\title{
Genetic diversity and chemical profiling of different populations of Convolvulus pluricaulis (convolvulaceae): an important herb of ayurvedic medicine
}

\author{
Showkat Hussain Ganie • Zahid Ali • \\ Sandip Das • Prem Shankar Srivastava • \\ Maheshwar Prasad Sharma
}

Received: 28 March 2014/Accepted: 27 May 2014/Published online: 18 June 2014

(c) The Author(s) 2014. This article is published with open access at Springerlink.com

\begin{abstract}
Convolvulus pluricaulis Choisy, commonly known as "Shankhpushpi", is an ayurvedic medicinal plant recommended as a brain tonic to promote intellect and memory, eliminate nervous disorders and to treat hypertension. Because of increasing demand of the drug, this plant species has been over-exploited. As a consequence, many unrelated plants are being sold by the crude drug dealers in India in the name of "Shankhpushpi". Information on its existing gene pool is currently lacking. We developed molecular (Random Amplification of Polymorphic DNA) and chemical (high performance liquid chromatography) markers that could distinguish the genuine plant species from its adulterants. Molecular characterization confirmed higher genetic variation at inter-zonal level as compared to intra-zonal populations. A total of 37 reproducible amplicons were generated of which 22 were polymorphic. The number of amplicons was in the range of 6-11 and genetic distance for the studied primers ranged from 0.07 to 0.34 . Fifty nine per cent polymorphism was obtained across different geographical locations. Dendrogram studied through unweighted pair group method of arithmetic analysis differentiated all the genotypes into two major clusters, Cluster I had the single population of
\end{abstract}

S. H. Ganie $(\bowtie) \cdot$ M. P. Sharma

Department of Botany, Jamia Hamdard, Hamdard Nagar,

New Delhi 110062, India

e-mail: showkatbotany@gmail.com

Z. Ali · P. S. Srivastava

Department of Biotechnology, Jamia Hamdard, Hamdard Nagar, New Delhi 110062, India

S. Das

Department of Botany, University of Delhi, New Delhi 110007, India
Rajasthan and Cluster II was represented by genotypes of Delhi, Haryana, Madhya Pradesh and Rajasthan. The Kaempferol content ranged from 0.07 to $0.49 \mathrm{mg} / \mathrm{g}$ and Delhi population was the highest accumulator.

Keywords Convolvulus pluricaulis - Genetic diversity · HPLC $\cdot$ Kaempferol · RAPD

\section{Introduction}

The indigenous plant-based systems of medicine (Ayurveda, Siddha and Unani) have been in existence for several centuries and continue to serve humanity for infinite time to come. The use of medicinal plants registered a decline with the development of synthetic drugs and antibiotics, but the toxicity and harmful side effects of synthetic drugs have again brought medicinal plants to the forefront of health care system. However, overpopulation and overexploitation of medicinal plants, particularly in the developing countries, have caused extensive damage to the medicinal plants wealth. Therefore, characterization and conservation of medicinal plants is the need of hour. Herbal medicinal materials are traditionally identified by their organoleptic or microscopic characteristics, including size, shape, colour, odour, flavour, texture and other physical properties. However, these methods are considered to be subjective because the morphological and chemical characters can be influenced by the environment and changes in different developmental stages. Molecular markers are not influenced by environmental factors; tests can be carried out at any time during any stage of plant development; they have the potential of existing in unlimited numbers, covering the entire genome. Moreover, a small amount of sample is sufficient for analysis. A 
number of PCR-based molecular markers have been used for detecting polymorphism at DNA level. Among them, random amplification of polymorphic DNAs (RAPD) gained much popularity because of its simplicity, nonrequirement of prior information of nucleotide sequence and can be performed with very small amount of genomic DNA. Random amplification of polymorphic DNA technique has been successfully employed for the estimation of genetic diversity; some of which include Plantago ovata (Singh et al. 2009), Ricinus communis (Gajera et al. 2010), Jatropha curcas (Zhang et al. 2011), Curcuma longa (Singh et al. 2012), Aloe vera (Nejatzadeh-Barandozi et al. 2012) and Clitoria ternatea (Yeotkar et al. 2012). In addition to DNA markers, phytochemical markers high performance liquid chromatography (HPLC) play a role to portray genetic variability and authentication of medicinally important plants ( $\mathrm{Li}$ et al. 2008). Hence, molecular and chemical characterization can go hand in hand rather than in isolation because such studies would be quite helpful for conservation strategies and the selection of population containing maximum content of active compound.

Convolvulus pluricaulis (Family: Convolvulaceae) is a prostrate spreading wild herb. In India it has a narrow distribution found in plains of Punjab, Uttar Pradesh, Haryana, Rajasthan, Bihar and Chota Nagpur (Sethiya and Mishra 2010). The plant is used in Ayurveda to cure various ailments. It is recommended as a brain tonic to promote intellect and memory, eliminate nervous disorders and to treat hypertension (Bala and Manyam 1999); is anti-helmintic, good in dysentery, hair tonic, cures skin ailments and reduces high blood pressure (Rai 1987). The leaves are recommended for depression and mental disturbance (Singh and Mehta 1977). The herb has been widely used to treat nervous disorders, similar to the use of kava kava (Piper methysticum) and valerian (Valeriana officinalis) prescribed by American herbalists (Husain et al. 2007).

The plant shows the presence of alkaloids, glycosides, coumarins and flavonoides (Bhowmik et al. 2012). One of the flavonoid in C. pluricaulis is Kaempferol (Andrade et al. 2012); it is reported to have significant biological activity being used for chemo-preventive purposes like inhibition of cell growth (Jin et al. 1995), induction of apoptosis (Jin et al. 1995; Braig et al. 2005; Chen and Kong 2005; Niering et al. 2005) and inhibition of proteasome activity (Chen and Kong 2005).

Being found in open waste lands, the natural populations of this herb has depleted to a great extent due to overexploitation and habitat degradation, especially in urban areas, and therefore, need protection. This species, therefore, appears well suited for study using molecular and chemical markers to determine its genetic diversity. The

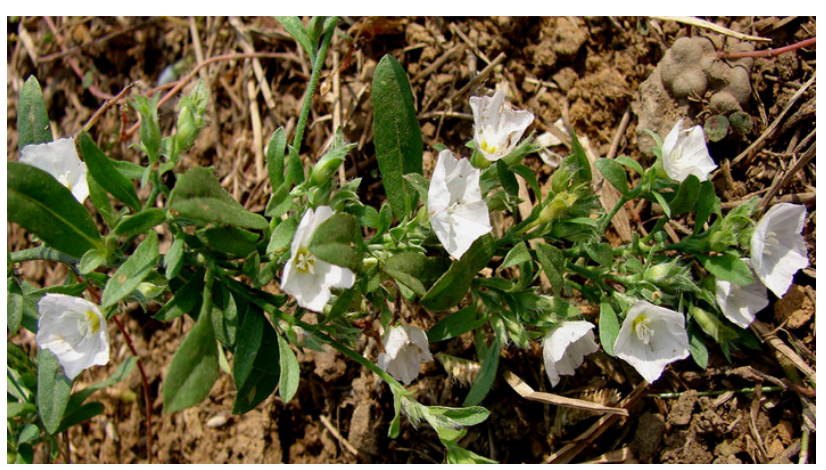

Fig. 1 Convolvulus pluricaulis

present study is based on RAPD and HPLC analyses, of the materials collected from different locations in India.

\section{Materials and methods}

The samples of C. pluricaulis were collected from Aravali foothills (Delhi and Kurukshetra, Haryana), Gangetic Plains (Lucknow, Uttar Pradesh), Arid zone (Jodhpur, jaipur, Udaipur, Rajasthan) and Vindhyachal (Bhopal, Madhya Pradesh). Whole herb was collected, transferred to sealable polythene bags and transported to the laboratory within 10-24 $\mathrm{h}$ depending upon the distance from the collection site. The samples were subjected to stringent method of botanical identification (Fig. 1); voucher specimens of the same were prepared and are kept in the Herbarium, Department of Botany, Hamdard University, New Delhi, 110062. The identified specimens were compared with authenticated voucher specimens preserved in the herbarium of National Institute of Science Communication and Information Resources (NISCAIR). The lyophilized leaves were used for DNA isolation. A part of the plant material was dried at $40{ }^{\circ} \mathrm{C}$ for HPLC analysis.

DNA isolation and RAPD assay

The modified CTAB protocol of Doyle and Doyle (1990) and purification kit (HiPurA) were used to isolate DNA from the leaves. The leaves $(1 \mathrm{~g})$ were pulverized to fine powder using liquid nitrogen in a chilled mortar and pestle followed by the addition of $100 \mathrm{mg}$ of PVP (insoluble) and $10 \mathrm{ml}$ pre-heated CTAB buffer (CTAB $2 \%, 2 \mathrm{M}$ Sodium Chloride, $100 \mathrm{mM}$ Tris HCl- $\mathrm{pH} \mathrm{8,} 20 \mathrm{mM}$ EDTA). The slurry was transferred into autoclaved $50 \mathrm{ml}$ centrifuge tube and incubated at $60{ }^{\circ} \mathrm{C}$ for $1 \mathrm{~h}$. After incubation, the tubes were kept at room temperature for $20 \mathrm{~min}$ and $10 \mathrm{ml}$ of chloroform, isoamyl alcohol $\left(\mathrm{CHCl}_{3}\right.$ : IAA, $\left.24: 1\right)$ was added and mixed carefully for $15 \mathrm{~min}$. The content was centrifuged at $8,000 \mathrm{rpm}$ for $15 \mathrm{~min}$ at $15{ }^{\circ} \mathrm{C}$. The upper 
phase was collected in fresh autoclaved centrifuge tubes to which $10 \mu \mathrm{g} / \mathrm{ml}$ of RNAase was added and the tubes were incubated at $37{ }^{\circ} \mathrm{C}$ for $30 \mathrm{~min}$. To inactivate RNAase A, $10 \mathrm{ml} \mathrm{CHCl}_{3}$ : IAA $(24: 1)$ was added and the content was centrifuged at 8,000 rpm for $15 \mathrm{~min}$ at $15^{\circ} \mathrm{C}$. The upper phase was transferred again into autoclaved centrifuge tube and 0.5 vol of $3 \mathrm{M}$ Potassium acetate $(\mathrm{pH}$ 5.2) was added. To precipitate the DNA, two volumes of chilled absolute ethanol was used and the tubes were kept at $-20{ }^{\circ} \mathrm{C}$ for $2 \mathrm{~h}$. It was recentrifuged at 8,000 rpm for $15 \mathrm{~min}$ at $4{ }^{\circ} \mathrm{C}$. The supernatant was discarded and the pellet was washed with $70 \%$ ethanol, air dried and dissolved in $250 \mu \mathrm{l}$ of sterile water. The DNA obtained was not ideal for PCR analysis and therefore was purified by DNA purification kit (HiPurA, India) according to manufacturer's instructions.

The polymerase chain reaction was carried out in $15 \mu \mathrm{l}$ reaction volume containing $50 \mathrm{ng}$ DNA, 0.5 units Taq DNA polymerase, $1.66 \mathrm{mM} \mathrm{MgCl}_{2}, 30 \mathrm{pmol} 11$-mer primers, $200 \mu \mathrm{M}$ of each dNTPs, $1 \times$ Taq polymerase buffer. The final volume was made up with sterile MilliQ water. The amplifications were carried out in DNA thermal cycler (Eppendorf, Germany). The PCR amplification conditions for RAPD consisted of initial step of denaturation at $94{ }^{\circ} \mathrm{C}$ for $4 \mathrm{~min}, 35$ cycles of denaturation at $94{ }^{\circ} \mathrm{C}$ for $1 \mathrm{~min}$, annealing at $35^{\circ} \mathrm{C}$ for $1 \mathrm{~min}$, extension at $72^{\circ} \mathrm{C}$ for $2 \mathrm{~min}$, followed by final extension at $72{ }^{\circ} \mathrm{C}$ for $10 \mathrm{~min}$. The amplified DNA was loaded on $1.2 \%$ agarose gel in $0.5 \times \mathrm{TBE}$ buffer containing $10 \mu \mathrm{l}$ of $\mathrm{EtBr}(10 \mathrm{mg} / \mathrm{ml})$ and photographed using gel documentation system (UVP, Germany). Lambda DNA EcoR 1- Hind 111 double digest was used as molecular marker (Bangalore Genei, Bangalore, India) to know the size of the fragments. Twenty-five 11-mer RAPD primers of OPN and G series, purchased from Eurofins MWG Operon, Germany), were screened. The data analysis was carried out by band scoring of wellmarked amplified fragments.

Data and statistical analysis

PCR products were scored for the presence (1) or absence (0) irrespective of band intensity since each product of identical molecular weight was supposed to represent a single locus. Genetic analysis was carried out using Nei genetic similarity index (Nei and Li 1979) using the formula $F_{x y}=2 n_{x y} /\left(\mathrm{n}_{x}+\mathrm{n}_{y}\right)$, where $n_{x y}$ is the number of common RAPD fragments shared by two samples and $n_{x}$ and $n_{y}$ are the total number of bands scored in each sample. The genetic distance was calculated using Hillis and Mortiz equation (1990), $D=1-\mathrm{F}$, where " $F$ " is species similarity. The dendrogram was constructed using the NTSYS-pc software (Numerical taxonomy and multivariate system) (Rohlf 1993).

\section{HPLC analysis}

The leaf powder (400 mg) was first defatted by preextraction with $20 \mathrm{ml}$ chloroform and refluxed for $1 \mathrm{~h}$ with $30 \mathrm{ml} 95 \%$ aqueous methyl alcohol $(\mathrm{MeOH})$ and $9 \mathrm{ml}$ of $25 \%$ hydrochloric acid. After filtration with Whatman paper, the samples were extracted twice with $20 \mathrm{ml}$ of $\mathrm{MeOH}$ for $10 \mathrm{~min}$. The combined hydrolysates were diluted with $\mathrm{MeOH}$ to $100 \mathrm{ml}$ and filtered through syringe filter $(0.45 \mu \mathrm{m})$. Each extract was injected in triplicate. The kaempferol reference standard (Sigma) in different concentrations was prepared in parallel to generate standard curve for quantification. Kaempferol quantification was made by comparing its retention time of the peak area with the Kaempferol peak area from the standard. The retention time of standard Kaempferol was 2.13. HPLC analysis conditions were: Waters 600E HPLC system equipped with $125 \times 4 \mathrm{~mm}$ C18 column with PDA detector 996 and auto sampler 2701. The mobile phase was $2 \%$ acetic acid and methanol: acetic acid: water $(18: 18: 1 \mathrm{v} / \mathrm{v})$ at $1 \mathrm{ml} / \mathrm{min}$ constant flow rate, $35^{\circ} \mathrm{C}$ column temperature and $370 \mathrm{~nm}$ wavelength for detection. The injection volume was $20 \mu \mathrm{l}$.

\section{Results and discussion}

In order to study the diversity at DNA level in C. pluricaulis, 25 primers were used for RAPD analysis. Only five primers generated clear and reproducible bands, with the size range of $0.5-2.0 \mathrm{~kb}$. A total of 37 bands (Table 1), with an average of 7.4 bands per primer, were produced.

Table 1 RAPD data and percentage of polymorphism in C. pluricaulis

\begin{tabular}{lllllrr}
\hline S. no & Primer code & $\begin{array}{l}\text { Nucleotide } \\
\text { sequence }\left(5^{\prime}-3^{\prime}\right)\end{array}$ & $\begin{array}{l}\text { Total no. } \\
\text { of bands }\end{array}$ & $\begin{array}{l}\text { Polymorphic } \\
\text { bands }\end{array}$ & \% Monomorphism & Polymorphism \\
\hline 1 & OPN-01 & CCTCAGCTTGG & 11 & 09 & 18.82 & 81.18 \\
2 & OPN-02 & AACCAGGGGCA & 07 & 05 & 28.58 & 71.42 \\
3 & OPN-04 & GGACCGACCCA & 06 & 06 & 0.00 & 100.00 \\
4 & OPN-09 & TTGCCGGCTTG & 07 & 01 & 85.72 & 14.28 \\
5 & G-01 & ATGCTCTGCCC & 06 & 01 & 83.34 & 16.66 \\
& Average & & 37 & 22 & 40.55 & 59.45 \\
\hline
\end{tabular}


Number of polymorphic bands per primer ranged from 01 to 09 with an average of 4.8 polymorphic bands per primer. The mean percentage of polymorphic bands was 59.45 . Such average polymorphism might be due to non-effective gene flow, low fecundity, low pollen flow, local selection procedure (environment and struggle for existence), inbreeding systems (Loveless and Hamrick 1984), biotic factors like human interference, habitat destruction and commercial exploitation (Vijay et al. 2009). The earlier work carried out on similar aspects lend support to our study that also recorded average polymorphism at individual provenance/genotype level in Lycoris longituba (65. $96 \%$, Deng et al. 2006), Asparagus racemosus (54.92\%, Vijay et al. 2009), Typha angustifolia (71\%, Na et al. 2010).

The primers OPN-04, OPN-01 and OPN-02 generated highest percentage polymorphisms $(100,81$ and 71.42 , respectively), and the lower polymorphisms (16.66 and $14.28 \%$ ) were obtained with G-01 and OPN-09 (Figs. 2, $3)$. Of the total bands generated, 15 were monomorphic across all the genotypes. The genetic similarity and distance was in the range of $0.66-0.93$ and $0.07-0.34$, respectively (Table 2).

Population-specific bands generated through different primers represented the identification marks for various genotypes. The unique bands of 0.8 and $0.6 \mathrm{~kb}$ amplified by primer OPN-01, one band of $0.35 \mathrm{~kb}$ amplified by OPN02 and bands of 2.1 and $1.0 \mathrm{~kb}$ developed by primer OPN09 are specific to Rajasthan genotypes. The drug Shankhpushpi is being equated with three different plant species (Clitoria ternatea, Convolvulus pluricaulis and Evolvulus alsinoides); studies based on relative efficacy and usage suggest that $C$. pluricaulis can be considered as the actual source, while E. alsinoides and C. ternatea as the alternative sources of Shankhpushpi (Nair et al. 1997). In addition to these three plants, different unrelated drugs are being sold in crude drug markets of India in the name of Shankhpushpi (Singh and Viswanathan 2001). The specific bands obtained, therefore, will help distinguish the authentic drug from its substitutes and adulteraterants. Molecular markers have been used in the identification of herbal drugs (Rout 2006; Rivera-Arce et al. 2007; Irshad et al. 2009; Heubl 2010; Ganie et al. 2012).

The similarity coefficients were used to generate a tree for cluster analysis using the UPGMA method. The resulting dendrogram differentiated two major clusters. First represented a solitary genotype of Jodhpur (Rajasthan) and the second, the genotypes of Kurukshetra (Haryana), Delhi, Bhopal (Madhya Pradesh), Udaipur, Jaipur (Rajasthan) and Lucknow (Uttar Pradesh) (Fig. 4). The genotypes of Delhi and Bhopal shared highest level of similarity coefficient (0.87). The sample collected from

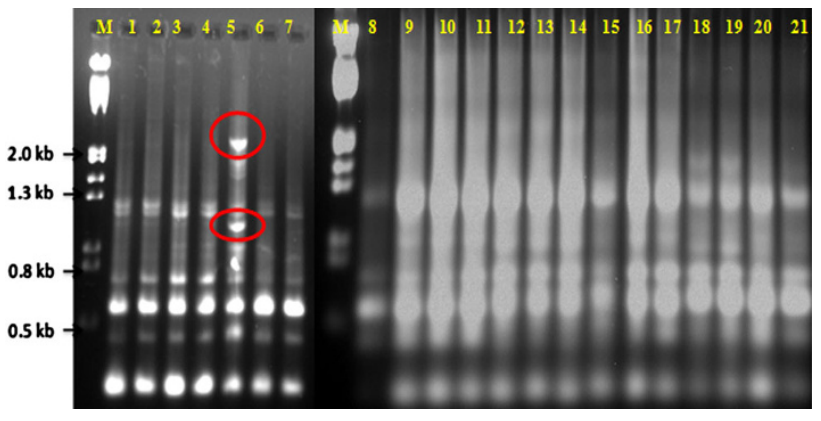

Fig. 2 RAPD fingerprint obtained with OPN-09 primer in different accessions of $C$. pluricaulis: $M$ Marker ( $\lambda$ DNA digested with Hind III and EcoR I); 1, 2 Kurukshetra Campus (Haryana); 3, 4 Arjun Herbal Park Kurukshetra (Haryana); 5 Jodhpur (Rajasthan); 6, 7 Lucknow (Uttar Pradesh); 8-11 Hamdard Campus (Delhi); 12-15 Bhopal (Madhya Pradesh); 16-18 Udaipur (Rajasthan); 19-21 Jaipur (Rajasthan). Circles represent region-specific bands

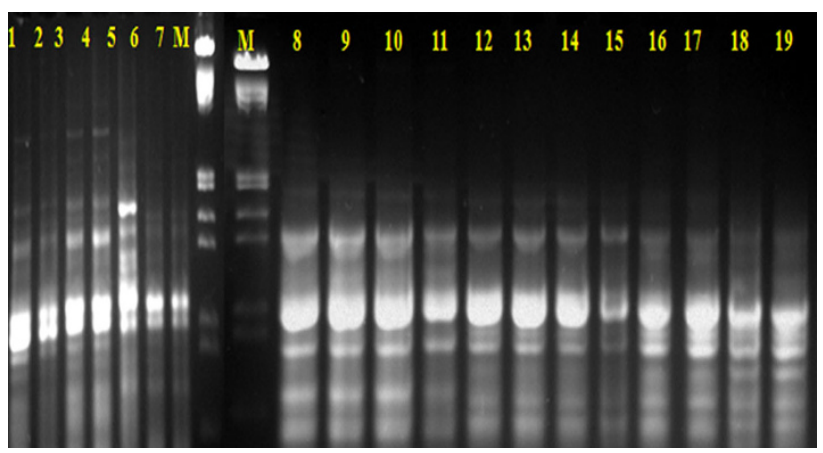

Fig. 3 RAPD fingerprint obtained with G-01 primer in different accessions of $C$. pluricaulis: $M$ Marker ( $\lambda$ DNA digested with Hind III and EcoR I); 1, 2 Kurukshetra Campus (Haryana); 3, 4 Arjun Herbal Park Kurukhshetra (Haryana); 5 Jodhpur (Rajasthan); 6, 7 Lucknow (Uttar Pradesh); 8-11 Hamdard Campus (Delhi); 12-15 Bhopal (Madhya Pradesh); 16-17 Udaipur (Rajasthan); 18-19 Jaipur (Rajasthan)

Table 2 Average genetic distance in different genotypes of $C$. pluricaulis

\begin{tabular}{lllllllll}
\hline Genotype & 01 & 02 & 03 & 04 & 05 & 06 & 07 & 08 \\
\hline 01 & - & 0.07 & 0.27 & 0.14 & 0.09 & 0.08 & 0.23 & 0.18 \\
02 & 0.07 & - & 0.25 & 0.15 & 0.11 & 0.16 & 0.20 & 0.26 \\
03 & 0.27 & 0.25 & - & 0.30 & 0.34 & 0.29 & 0.31 & 0.30 \\
04 & 0.14 & 0.15 & 0.30 & - & 0.17 & 0.16 & 0.14 & 0.20 \\
05 & 0.09 & 0.11 & 0.34 & 0.17 & - & 0.07 & 0.11 & 0.17 \\
06 & 0.08 & 0.16 & 0.29 & 0.16 & 0.07 & - & 0.11 & 0.13 \\
07 & 0.23 & 0.20 & 0.31 & 0.14 & 0.11 & 0.11 & - & 0.14 \\
08 & 0.18 & 0.26 & 0.30 & 0.20 & 0.17 & 0.13 & 0.14 & - \\
\hline 01 & & & & & & &
\end{tabular}

01 Haryana (Kurukshetra Campus), 02 Haryana (Arjun Herbal ParkKurukshetra), 03 Rajasthan (Jodhpur), 04 Uttar Pradesh (Lucknow), 05 Delhi (Hamdard Campus), 06 Madhya Pradesh (Bhopal), 07 Rajasthan (Udaipur), 08 Rajasthan (Jaipur) 
Fig. 4 Dendrogram showing the similarity coefficients in different accessions of $C$. pluricaulis. Har. 1 (Haryana, Kurukshetra Campus), Har. 2 (Haryana, Arjun Herbal Park, Kurukshetra), Del (Delhi, Hamdard Campus), M. P. (Madhya Pradesh, Bhopal), Raj. (Rajasthan-Udaipur, Jaipur and Jodhpur), U. P. (Uttar pradesh, Lucknow)

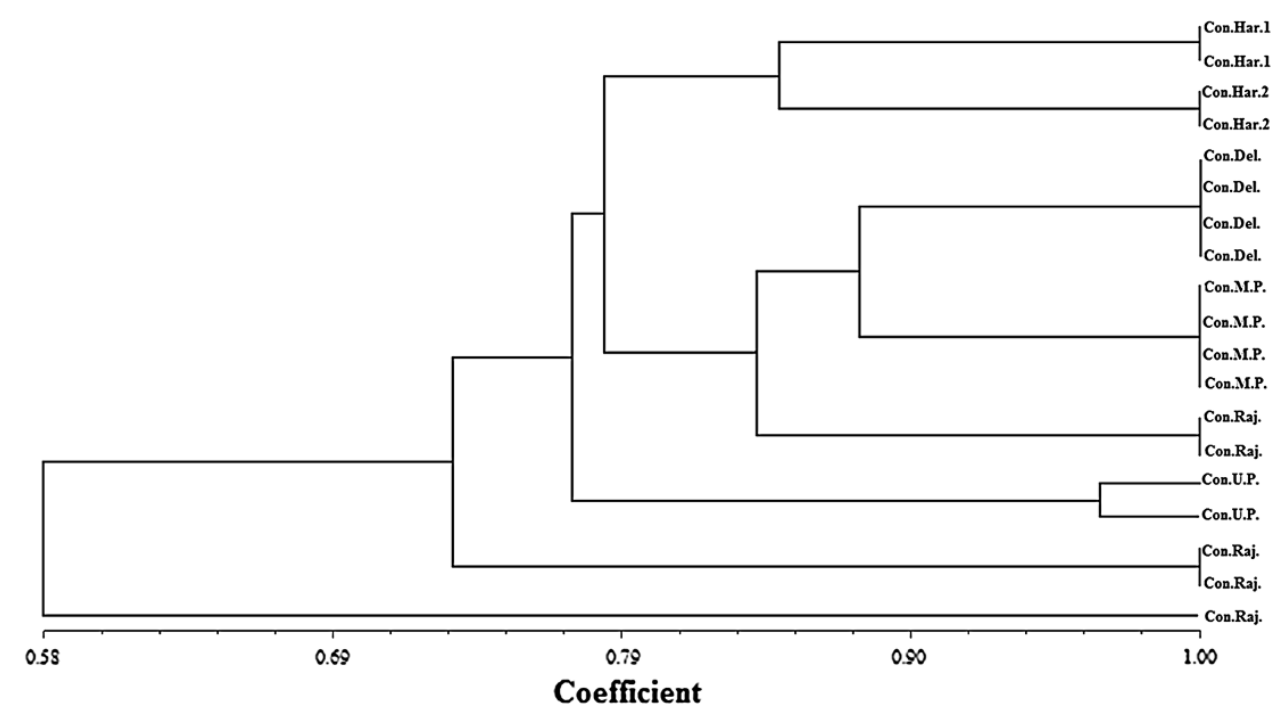

Jodhpur (Rajasthan) had the highest degree of divergence and shared a similarity coefficient of only 0.58 with the rest of the genotypes. The intra-zonal diversity was maximum among Rajasthan populations followed by Haryana populations whereas in other samples, intra-zonal diversity was negligible. The clustering obtained was not region specific, thus showing the lack of any defined population structure in this species. Similar finding have been reported for Prunus cerasifera (Ayanoglu et al. 2007) and Punica granatum (Jbir et al. 2008). However, Ali et al. (2013) reported well-structured clustering in Clitoria ternatea and Belaj et al. (2010) for Andalusian and most Catalonian olive cultivars. Other than Rajasthan genotypes that remained scattered all over the dendrogram, all other genotypes formed perfect clusters by remaining confined within their respective clades.

The HPLC analysis also showed considerable variation in kaempferol content in different genotypes investigated. The results are presented in Table 3. Delhi population was found to be the highest accumulator $(0.495 \pm 0.014 \mathrm{mg} / \mathrm{g}$ dry wt) of kaempferol, followed by populations of Haryana $(0.375 \pm 0.002 \mathrm{mg} / \mathrm{g}$ dry wt), and the least kaempferol content was observed in Madhya Pradesh $(0.076 \pm 0.002 \mathrm{mg} / \mathrm{g}$ dry wt) populations (Fig. 5). The plant collection was made in different geographical locations; variation found, therefore, might be due to different environmental conditions. However, variation in kaempferol content could also be due to intra-specific nucleotide sequence differences. Hence, both genetic as well as environmental factors may be responsible for variation in kaempferol. The variation could be correlated by Sabu et al. (2001) equation: $\mathrm{VK}=\mathrm{VG}+\mathrm{VE}$, where $\mathrm{VK}$ is the variation in kaempferol content, $\mathrm{VG}$ is the genetic variance and VE is the environmental variance. The average climate of a particular geographical region remains almost
Table 3 Kaempferol content in different samples of $C$. pluricaulis

\begin{tabular}{lll}
\hline S. no & Plant samples & $\begin{array}{l}\text { Amount of kaempferol } \\
(\mathrm{mg} / \mathrm{g} \text { dry wt }) \pm \mathrm{SE}\end{array}$ \\
\hline 1 & Delhi, Hamdard Campus & $0.495 \pm 0.014$ \\
2 & Haryana, Kurukshetra & $0.375 \pm 0.002$ \\
3 & Uttar Pradesh, Lucknow & $0.184 \pm 0.007$ \\
4 & Rajasthan, Jodhpur & $0.279 \pm 0.003$ \\
5 & Rajasthan, Jaipur & $0.23 \pm 0.002$ \\
6 & Rajasthan, Udaipur & $0.19 \pm 0.001$ \\
7 & Madhya Pradesh, Bhopal & $0.076 \pm 0.002$ \\
\hline
\end{tabular}

constant; therefore, our aim was to screen the different populations of $C$. pluricaulis on the basis of kaempferol content. Furthermore, secondary metabolite content generally increases with the maturity and hence, the genotypes were collected at the flowering stages.

Though simultaneous molecular and chemical characterization is rare in medicinal plants, there are some reports where both the techniques have been taken into consideration. Boszormenyi et al. (2009) correlated RAPD profile with the essential oil composition among sage cultivars. Han et al. (2008) studied the genetic and chemical profile in different populations of Fructus xanthii in China. Similarly genetic and the terpenoid profile of Zataria multiflora collected from different locations in Iran have been analyzed (Hadian et al. 2011).

On the basis of differences in kaempferol content, the populations of $C$. pluricaulis could be divided into three groups. The first group comprised the accessions of Delhi and Haryana $(0.495,0.375)$, the group II, genotypes of Rajasthan (Jodhpur, Jaipur and Udaipur) and Uttar Pradesh $(0.279,0.23,0.19$ and 0.184$)$, and the group III represented accession from Madhya Pradesh (0.076). Other than kaempferol, a number of medicinally important secondary 
Fig. 5 Chromatograms showing kaempferol content of C. pluricaulis collected from (a) Delhi, (b) Madhya Pradesh (a)

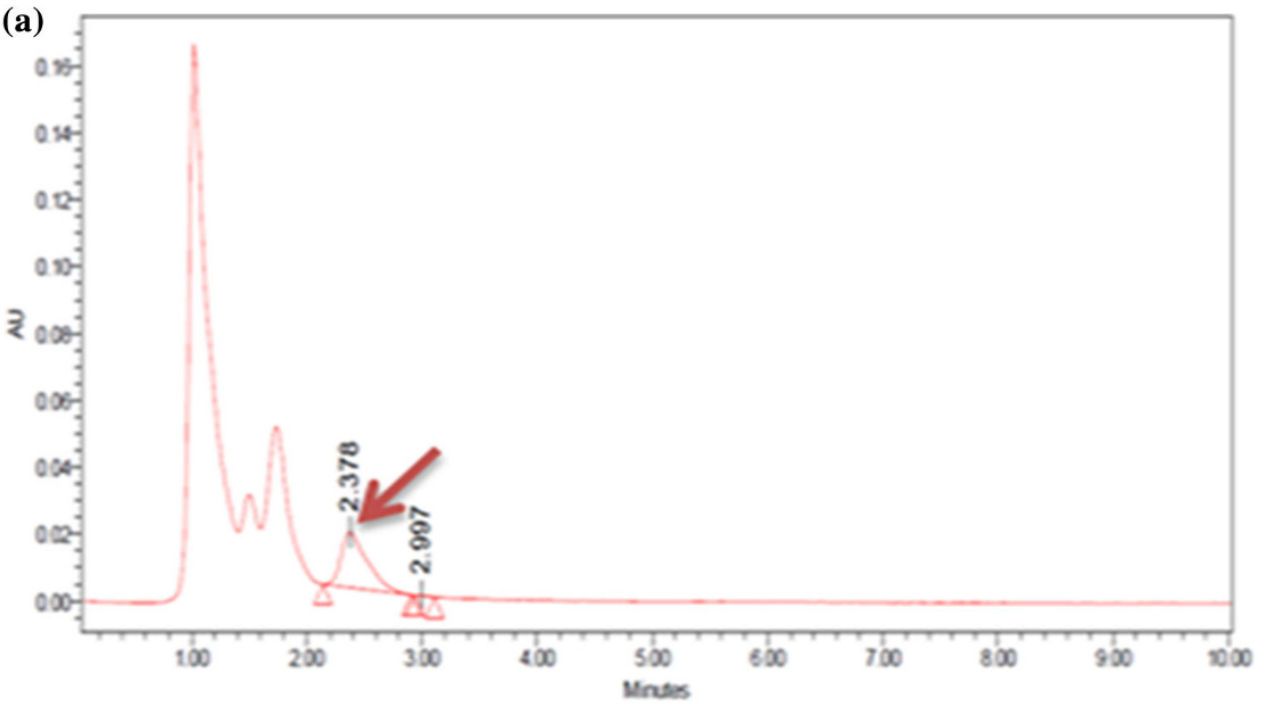

(b)

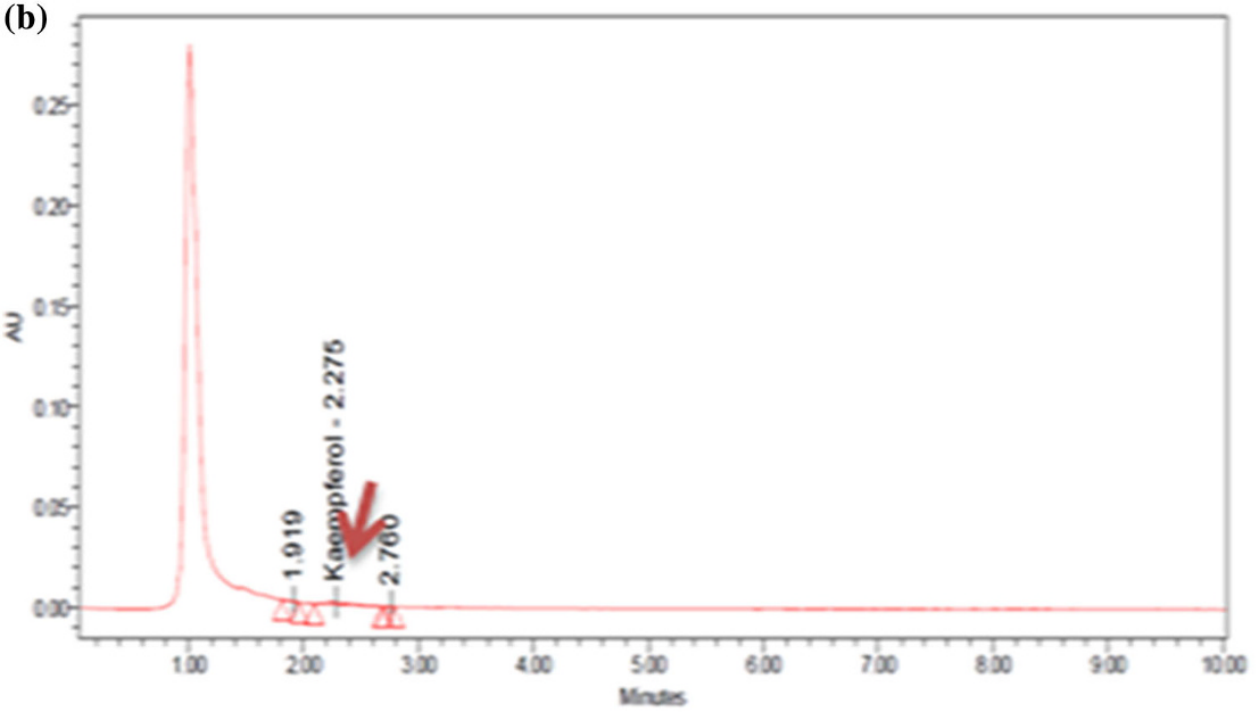

metabolites of $C$. pluricaulis have also been isolated of which scopoletin has been quantified by HPLC using different solvent systems (Kapadia et al. 2006; Upadhyay et al. 2013). The scopoletin content obtained by Upadhyay et al. (2013) was highest in hydro-alcoholic extract $(0.1738 \%)$ followed by methanolic extract $(0.0932 \%)$ and aqueous extract $(0.0435 \%)$. Our results declared that the herb contained less kaempferol in comparison to scopoletin. Delhi populations being rich in kaempferol may potentially be multiplied and used on a large scale for commercial cultivation. The kaempferol content could further be increased by tissue culture and transformation studies. Our next focus is to isolate the kaempferol from C. pluricaulis and determine its anti-cancer activity using rat models.

A comparative molecular and chemical analysis of different population of $C$. pluricaulis was achieved in this work.
RAPD technology could be efficiently used to demonstrate genetic relationships among different populations of $C$. pluricaulis. By analysing the genetic and chemical profiling, it is possible to identify the elite population. This information could be employed for devising strategies for authentication and conservation of $C$. pluricaulis.

Acknowledgments This work was financed by the National Medicinal Plants Board, Ministry of Health and Family Welfare, Government of India. The authors are thankful to unknown reviewers for their constructive suggestions that helped us to reshape the manuscript.

Conflict of interest There is no conflict of interest.

Open Access This article is distributed under the terms of the Creative Commons Attribution License which permits any use, distribution, and reproduction in any medium, provided the original author(s) and the source are credited. 


\section{References}

Ali Z, Ganie SH, Narula A, Sharma MP, Srivastava PS (2013) Intra-specific genetic diversity and chemical profiling of different accessions of Clitoria ternatea L. Ind Crops Prod 43:768-773

Andrade C, Monteiro I, Hegde RV, Chandra JS (2012) Investigation of the possible role of Shankapushpi in the attenuation of ECT induced amnestic deficits. Indian J Psychiatry 54:166-171

Ayanoglu H, Bayazit S, Inan G, Bakır M, Akpınar AE, Kazan K, Ergu 1A (2007) AFLP analysis of genetic diversity in Turkish green plum accessions (Prunus cerasifera L.) adapted to the Mediterranean region. Sci Hortic 114:263-267

Bala V, Manyam MD (1999) Dementia in Ayurveda. J Altern Complement Med 5:81-88

Belaj A, Munoz-Diez C, Baldoni L, Satovic Z, Barranco D (2010) Genetic diversity and relationships of wild and cultivated olives at regional level in Spain. Sci Hortic 124:323-330

Bhowmik D, Kumar KPS, Paswan S, Srivatava S, Yadav A, Dutta A (2012) Traditional Indian herbs Convolvulus Pluricaulis and its medicinal importance. J Pharmacogn Phytochem 1:44-51

Boszormenyi A, Hethelyi E, Farkas A, Horvath G, Papp N, Lemberkovics E, Szoke E (2009) Chemical and genetic relationships among sage (Salvia officinalis L.) cultivars and judean sage (Salvia judaica Boiss.). J Agric Food Chem 57:4663-4667

Braig M, Lee S, Loddenkemper C, Rudolph C, Peters AH, Schlegelberger B, Stein H, Dorken B, Jenuwein T, Schmitt CA (2005) Oncogene-induced senescence as an initial barrier in lymphoma development. Nature 436:660-665

Chen C, Kong AN (2005) Dietary cancer-chemopreventive compounds: from signalling and gene expression to pharmacological effects. Trends Pharmacol Sci 26:318-326

Deng CL, Zhou J, Gao WJ, Sun FC, Qin RY, Lu LD (2006) Assessment of genetic diversity of Lycoris longituba (Amaryllidaceae) detected by RAPDs. J Genet 85:05-207

Doyle JJ, Doyle JL (1990) Isolation of plant DNA from fresh tissue. Focus 12:13-15

Gajera BB, Kumar N, Singh AS, Punvar BS, Ravikiran R, Subhash N, Jadeja GC (2010) Assessment of genetic diversity in castor (Ricinus communis L.) using RAPD and ISSR markers. Ind Crops Prod 32:491-498

Ganie SH, Srivastava PS, Narula A, Ali Z (2012) Authentication of shankhpushpi by RAPD markers. Eurasia J Biosci 6:39-46

Hadian J, Ebrahimib SN, Mirjalilia MH, Azizi A, Ranjbard H, Friedtc W (2011) Chemical and genetic diversity of Zataria multiflora Boiss. accessions growing wild in Iran. Chem Biodiv 8:176-188

Han T, Hu Y, Zhou SY, Li HL, Zhang QY, Zhang H, Huang BK, Rahman K, Zheng HC, Qin LP (2008) Correlation between the genetic diversity and variation of total phenolic acids contents in Fructus Xanthii from different populations in China. Biomed Chromatogr 5:478-486

Heubl G (2010) New aspects of DNA-based authentication of Chinese medicinal plants by molecular biological techniques. Planta Med 76:1963-1974

Hillis DM, Moritz C (1990) Molecular systematics. Sinauer Associates, Sunderland

Husain GM, Mishra D, Singh PN, Rao CV, Kumar V (2007) Ethnopharmacological review of native traditional medicinal plants for brain disorders. Phoog Rev 1:20-29

Irshad S, Singh J, Kakkar P, Mehrotra S (2009) Molecular characterization of Desmodium species- an important ingredient of 'Dashmoola' by RAPD analysis. Fitoterapia 80:115-118

Jbir R, Hasnaoui N, Mars M, Marrakchi M, Trifi M (2008) Characterization of Tunisian pomegranate (Punica granatum L.) cultivars using amplified fragment length polymorphism analysis. Sci Hortic 115:231-237

Jin X, Nguyen D, Zhang WW, Kyritsis AP, Roth JA (1995) Cell cycle arrest and inhibition of tumor cell proliferation by the p16INK4 gene mediated by an adenovirus vector. Cancer Res 55:3250-3253

Kapadia NS, Acharya NS, Acharya SA, Shah MB (2006) Use of HPTLC to establish a distinct chemical profile for Shankhpushpi and for quantification of scopoletin in Convolvulus pluricaulis and in commercial formulations of Shankhpushpi. J Planar Chromatogr 19:195-199

Li WF, Jiang JG, Chen J (2008) Chinese medicine and its modernization demands. Arch Med Res 39:246-251

Loveless MD, Hamrick JL (1984) Ecological determinants of genetic structure in plant populations. Ann Rev Ecol Syst 27:237-277

Na HR, Kim C, Choi HK (2010) Genetic relationship and genetic diversity among Typha taxa from East Asia based on AFLP markers. Aquat Bot 92:207-213

Nair KV, Nair AR, Nair CPR (1997) Standardization of ayurvedic drugs. Bull Med Ethnobot Res 18:151-156

Nei M, Li WH (1979) Mathematical model for studying genetic variation in terms of restriction endonucleases. Proc Natl Acad Sci 76:5269-5273

Nejatzadeh-Barandozi F, Naghavi MR, Enferadi ST, Mousavi A, Mostofi Y, Hassani ME (2012) Genetic diversity of accessions of Iranian Aloe vera based on horticultural traits and RAPD markers. Ind Crops Prod 37:347-351

Niering P, Michels G, Watjen W, Ohler S, Steffan B, Chovolou Y, Kampkotter A, Proksch P, Kahl R (2005) Protective and detrimental effects of kaempferol in rat H4IIE cells: implication of oxidative stress and apoptosis. Toxicol Appl Pharmacol 209:114-122

Rai MK (1987) Ethnomedicinal Studies of Patalkot and Tamiya (Chhindwara): plants used as tonic. Anc Sci Life 3:119-121

Rivera-Arce E, Gattuso M, Alvarado R, Zarate E, Aguero J, Feria I, Lozoya X (2007) Pharmacognostical studies of the plant drug Mimosae tenuiflorae cortex. J Ethnopharmacol 113:400-408

Rohlf EJ (1993) NTSYS-pc: numerical taxonomy and multivariate analysis system. Version 1.80. Applied Biostatistics Inc., Setauket

Rout GR (2006) Identification of Tinospora cordifolia (Willd.) Miers ex Hook F \& Thomas using RAPD markers. Z Naturforsch C 6:118-122

Sabu KK, Padmesh P, Seeni S (2001) Intraspecific variation in active principle content and isozymes of Andrographis paniculata Nees (Kalmegh): a traditional hepatoprotective medicinal herb of India. J Med Aromat Plant Sci 23:637-647

Sethiya NK, Mishra SH (2010) Review on ethnomedicinal uses and phytopharmacology of memory boosting herb Convolvulus pluricaulis Choisy. Aust J Med Herbal 22:19-25

Singh RH, Mehta AK (1977) Studies on the psychotropic effect of the Medhya Rasayana drug 'Shankhpushpi' (Convolvulus pluricaulis) part 1 (Clinical Studies). J Res Indian Med Yog Homeo 12:3-18

Singh HB, Viswanathan MV (2001) Need for authentication of market samples of crude drug Shankhpushpi Convolvulus microphyllus. J Med Aromat Plant Sci 22:612-618

Singh N, Lal RK, Shasany AK (2009) Phenotypic and RAPD diversity among 80 germplasm accessions of the medicinal plant isabgol (Plantago ovata, Plantaginaceae). Genet Mol Res 8:1273-1284

Singh S, Panda MK, Nayak S (2012) Evaluation of genetic diversity in turmeric (Curcuma longa L.) using RAPD and ISSR markers. Ind Crops Prod 37:284-291

Upadhyay V, Sharma Tiwari K A, Joshi HM, Malik A, Singh B, Kalakoti SB (2013) Standardization of HPLC method of Scopoletin in different extracts of Convolvulus pluricaulis. Int J Pharm Sci Drug Res 5:28-31 
Vijay N, Sairkar P, Silawat N, Garg RK, Mehrotra NN (2009) Genetic variability in Asparagus racemosus(Willd.) from Madhya Pradesh, India by random amplified polymorphic DNA. Afr J Biotechnol 8:3135-3140

Yeotkar SD, Malode SN, Waghmare VN, Thakre P (2012) Genetic relationship and diversity analysis of Clitoria ternatea variants and Clitoria biflora using random amplified polymorphic DNA (RAPD) markers. Afr J Biotechnol 10:18065-18070

Zhang Z, Guo X, Liu B, Tang L, Chen F (2011) Genetic diversity and genetic relationship of Jatropha curcas between China and Southeast Asian revealed by amplified fragment length polymorphisms. Afr J Biotechnol 10:2825-2832 